\title{
A HOUSE OF HER OWN: OLD AGE ASSISTANCE AND THE LIVING \\ ARRANGEMENTS OF \\ OLDER NONMARRIED WOMEN
}

Dora L. Costa

Working Paper 6217 
NBER WORKING PAPER SERIES

\title{
A HOUSE OF HER OWN: OLD AGE ASSISTANCE AND THE LIVING ARRANGEMENTS OF OLDER NONMARRIED WOMEN
}

\author{
Dora L. Costa
}

Working Paper 6217

http://www.nber.org/papers/w6217

\section{NATIONAL BUREAU OF ECONOMIC RESEARCH 1050 Massachusetts Avenue \\ Cambridge, MA 02138 \\ October 1997}

I have benefited from the comments of Peter Diamond, Matthew E. Kahn, and the participants of the 1997 NBER/DAE Summer Institute. I would like to thank Irineu Carvalho for research assistance. I gratefully acknowledge the support of NIH grant AG12658. This paper is part of NBER's research programs in Aging and the Development of the American Economy. Any opinions expressed are those of the author and not those of the National Bureau of Economic Research.

(C) 1997 by Dora L. Costa. All rights reserved. Short sections of text, not to exceed two paragraphs, may be quoted without explicit permission provided that full credit, including $(\mathcal{O}$ notice, is given to the source. 
A House of Her Own: Old Age Assistance and the Living Arrangements of Older Nonmarried Women Dora L. Costa

NBER Working Paper No. 6217

October 1997

JEL Nos. J14, N12

Aging, Development of the American Economy

\begin{abstract}
I show that the trend towards single households among older nonmarried women, the majority of whom were widows, has been ongoing only since 1940 and investigate the factors that fostered the rise in separate living quarters since mid-century by examining the impact of Old Age Assistance on living arrangements in 1940 and 1950. I find that Old Age Assistance substantially increased demand for separate living quarters, but that demand depended upon the rules of the program, in particular whether children were held legally responsible for the care of their aged parents. I argue that almost half of the decline in the fraction of older nonmarried women living with relatives from 1950 to 1990 can be attributed to rising Social Security benefits and expanded eligibility and to the fact that Social Security benefits were given with no strings attached.
\end{abstract}

Dora L. Costa

Department of Economics

Massachusetts Institute of Technology

50 Memorial Drive

Cambridge, M $\Lambda 02139$

and NBER

costa@athena.mit.edu 


\section{Introduction}

In the past the majority of older nonmarried women lived in the households of their children or other relatives. Today only a small minority do so. This profound change in the social and economic life of older women is relatively recent. Until the 1940s and 1950s there was little change from one decade to another in the living arrangements of nonmarried women older than 64. Since the 1940 s and 1950 s increasing numbers of older nonmarried women have been living alone.

The timing of the decline in the proportion of older nonmarried women living with their relatives suggests that the institution of Social Security old age insurance and assistance in 1935, the steady growth of old age insurance after 1950, and the increase in survivors' benefits for older widows to 100 percent of the husband's benefit by 1972 may play an important role in explaining the decline in coresidence. ${ }^{1}$ Older women have always been more likely than older men to face poverty in old age and have therefore been more dependent than men upon family members or upon some form of public assistance for support. Of course, other factors may have contributed to the decline in coresidence. Declines in fertility and increases in life expectancy at older ages have offset decreases in child mortality and increased the ratio of aged parents to adult children. ${ }^{2}$ Improving health combined with changing household technology may now enable more older Americans to live alone. In addition, falling transportation costs may now permit them to migrate to areas with a lower cost of living and still maintain contact with their families. ${ }^{3}$

\footnotetext{
${ }^{1}$ See Michael, Fuchs, and Scott (1980) and Schorr (1960) for the impact of Social Security benefits on elderly living arrangements.

${ }^{2}$ See Wolf (1994) for a review of the literature on living arrangements and kin availability.

${ }^{3}$ See Longino (1990) for a review of the literature on elderly migration.
} 
Previous work on living arrangements and Social Security has focused on the 1970s and later years (e.g. Michael et al. 1980; Schwartz et al. 1984). But, the rise in the number of older nonmarried women living alone began several decades earlier. Previous work has sought to identify the impact of Social Security Old Age and Survivors' Insurance benefits from variation in payments in a single cross-section. But, factors that determine Social Security benefits, such as previous earnings of the beneficiary or of her husband, are likely to be correlated with living arrangements and thus confound the estimated effect of the program.

This paper investigates the factors that fostered the rise in separate living quarters for older nonmarried women by examining the impact of the primary program providing support for the elderly between 1940 and 1950 - Social Security Old Age Assistance. ${ }^{4}$ Although this need based program was later overshadowed by Old Age and Survivors' Insurance, in 194097 percent of combined Old Age and Survivors' Insurance and Old Age Assistance payments went to Old Age Assistance and in 195073 percent (Series H 238-244 and H 346-367 in U.S. Bureau of the Census 1975: 350,356 ). Because pension amount varied by state and was unrelated to the past earnings of the beneficiary or of her husband, I am able to use variation across states to identify the impact of Old Age Assistance. Because states responded to a change in the federal subsidization formula with a 27 percent benefit increase between 1940 and 1950, I am also able to use variation across time to identify the impact of Old Age Assistance. My findings have implications for the relative importance of income, including Social Security income, in explaining the rise in single, elderly households.

\footnotetext{
${ }^{4}$ This was a need based program. After 1950, when Old Age and Survivors' Insurance was liberalized, the program steadily declined in importance and in 1974 was incorporated into Supplemental Security Income.
} 
My findings also reveal the experiences of the old when social concern about the plight of older nonmarried women, the majority of whom were widows, was being formalized into federal law. When the 1938 Advisory Council on Social Security recommended that survivors' benefits for widows be enacted, it argued that,

A haunting fear in the minds of many older men is the possibility, and frequently the probability, that their widow will be in need after their death. The day of large families and of the farm economy, when aged parents were thereby assured comfort in their declining years, has passed for a large proportion of our population. This change has had a particularly devasting effect on the sense of sccurity of aged women of our country. ${ }^{5}$

The paper begins with an overview of the living arrangements of older nonmarried women. Although the trend since the 1940 s is well-known to researchers, many are unaware of the pre1940 pattern. Then, before proceeding to the empirical work, it discusses the living arrangements decision and how the Old Age Assistance program may have affected that decision.

\section{Trends}

Widowhood has always characterized women's experience of old age. Table 1 shows that the percentage of women older than 64 who were widows has always been extremely high. At the beginning of the century 60 percent were widowed. Although this figure has fallen to 50 percent,

\footnotetext{
${ }^{5}$ Reprinted in the Appendix to Brown (1977: Appendix page 27).
} 
Table 1: Marital Status Among Men and Women Older than 64

\begin{tabular}{rrrrrrr}
\multicolumn{3}{c}{ Men } & \multicolumn{3}{c}{ Women } \\
\hline & & \multicolumn{2}{l}{ Percent } & & & Percent \\
Year & Married & Widowed & Other & Married & Widowed & Other \\
\hline 1880 & 72.0 & 22.1 & 5.9 & 34.5 & 58.4 & 7.1 \\
1890 & 70.5 & 23.3 & 6.0 & 35.4 & 58.6 & 5.9 \\
1900 & 65.3 & 28.7 & 6.0 & 33.5 & 61.1 & 5.5 \\
1910 & 65.0 & 28.0 & 7.0 & 34.1 & 58.9 & 7.0 \\
1920 & 64.5 & 26.6 & 8.9 & 33.8 & 58.9 & 7.3 \\
1930 & 63.7 & 26.6 & 9.6 & 34.7 & 56.5 & 9.2 \\
1940 & 64.2 & 24.7 & 11.1 & 34.7 & 55.1 & 10.2 \\
1950 & 64.3 & 24.2 & 11.5 & 34.7 & 54.5 & 10.8 \\
1960 & 69.3 & 19.2 & 11.5 & 36.5 & 52.2 & 11.4 \\
1970 & 70.8 & 17.2 & 12.0 & 35.4 & 52.2 & 12.4 \\
1980 & 74.9 & 14.6 & 10.5 & 36.2 & 51.8 & 11.9 \\
1990 & 75.3 & 14.0 & 10.7 & 38.5 & 49.6 & 11.9 \\
\hline
\end{tabular}

Note. Estimated from the public use census samples (Ruggles and Sobek 1995). Estimates for 1890 and 1930 from Series A 160-171 in U.S. Bureau of the Census (1975: 20).

the increase in the number of divorced women has left the proportion of nonmarried women unchanged. In contrast, the percentage of nonmarried men older than 64 has always been low, largely because the percentage of widowers has always been low, representing 28 percent of the male population at the beginning of the century and 14 percent today.

Today differences in life expectancy account for much of the difference in widowhood rates between men and women, whereas in the past age differences between spouses were relatively more important. ${ }^{6}$ Age differences were higher in the past both because age differences in first

\footnotetext{
${ }^{6}$ A 20 year old woman today can expect to live 7 years longer than a 20 year old man. But, at mid-century she could expect to live only 3 years longer and at the turn of the century only one year longer (Preston, Keyfitz, and Schoen 1976; Table 115 in U.S. Bureau of the Census (1993: 85)). In the latter half of the nineteenth century, the mean age difference between spouses upon marriage was close to 5 and in the middle of this century close to 3 . These age differences are greater than those for age at first marriage between men and women which was 4 in 1880 , 3 in 1940, and 2 in 1990 (see Table 2 in Haines 1996).
} 
marriages for both husband and wife were higher and because when widowers remarried they wed never married women ten years their juniors. In contrast, women who became widowed at older ages were about half as likely to remarry (Beckenridge 1989).

Older widows often faced financial duress and were much more likely than married women to become dependent upon public assistance. ${ }^{7}$ Although this pattern continues to prevail today, before the institution of Social Security, many nonmarried women escaped poverty only through the support of their families, generally because children welcomed mothers or relatives into their homes. Figure 1 illustrates.

Figure 1 shows that differences in living arrangements by marital status were much larger in the past than they are today. Before 1940 more than half of all nonmarried women lived with family members, whercas in 1990 less than 15 percent did so. These households, in which the women were not listed as households heads, were predominantly the households of the children. When they were not, they were those of siblings, grandchildren, or nephews and nieces. A more detailed breakdown of living arrangements and marital status is provided in Appendix A.

Nonmarried women who lived apart from relatives circa 1950 were richer than those who did not, suggesting that income was one of the primary determinants of living arrangements (Steiner and Dorfman 1957: 202). But, for most women this income was not forthcoming until the passage of Social Security. In describing the benefits of Social Security to the U.S. Chamber of Commerce

\footnotetext{
${ }^{7}$ A 1928 study by the National Civic Federation of older Americans reported that whereas only 19 percent of married women owned no property, the figure for widows was 48 percent. The figures for single and divorced women were 30 and 60 percent, respectively. In 195123 percent of nonmarried women depended upon public assistance as their prinlary source of support, compared to 19 percent of nonmarried men and 12 percent of married couples (Epstein 1955). Even today, with a wider safety net in place, widowed women older than 64 are more than three times as likely to live in poverty as married women and the divorced and single are more than four times as likely (Burkhauser and Smeeding 1994).
} 
Figure 1: Percentage of Women Older than 64 Living with Family Members as Dependents by Marital Status

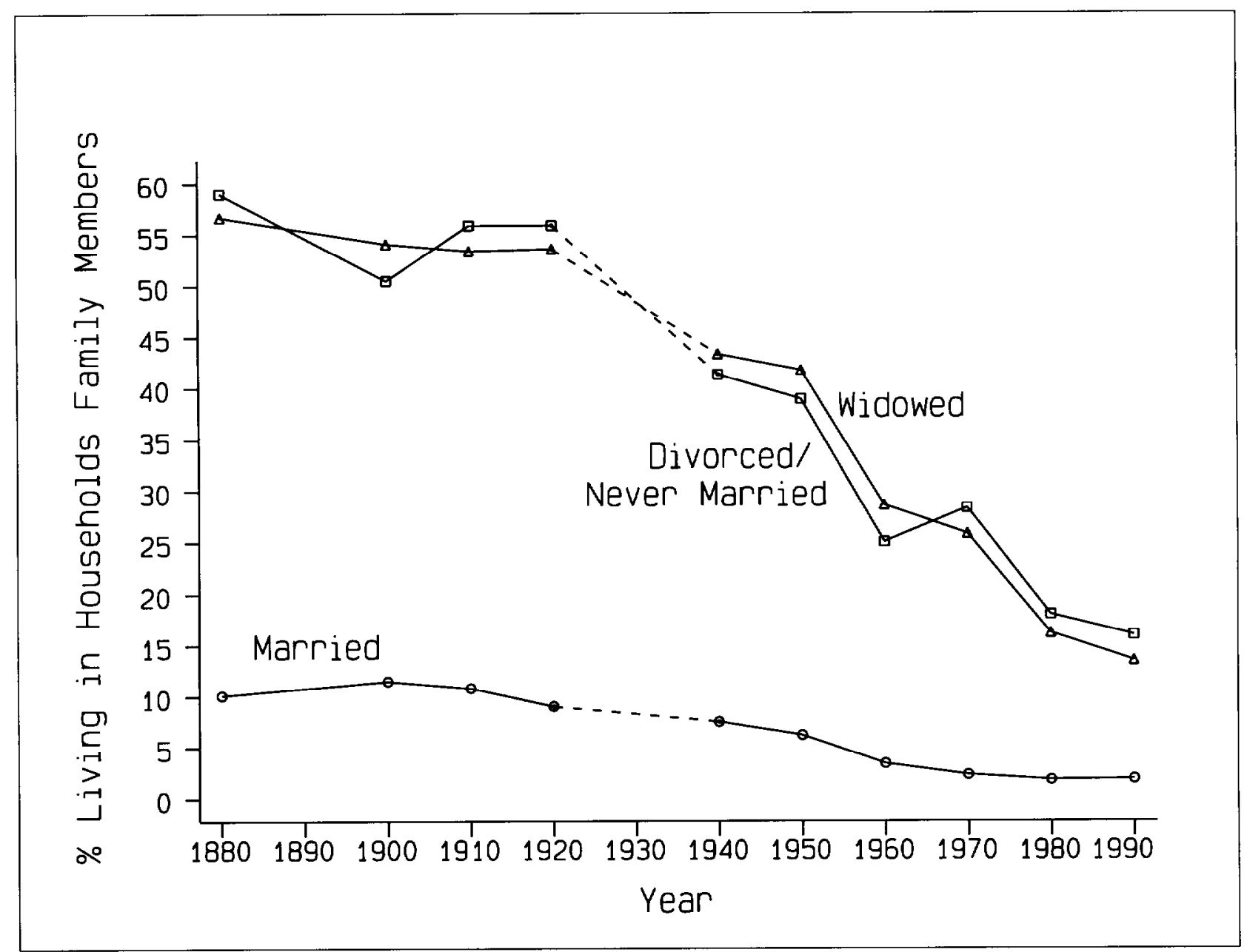

Note. Restricted to the noninstitutionalized. Because the published census volumes provide no information on elderly living arrangements, it is not possible to obtain figures for 1930. Estimated from the integrated public use census samples (Ruggles and Sobek 1995). 
in 1934, Eleanor Roosevelt declared that, "The community owes to its old people their own home life as long as they can possibly live at home. Old people love their own things even more than young people do. It means so much to sit in the same chair you sat in for a great many years; to see the same picture that you always looked at ... And that is what an old age security bill will do" (cited in Graebner 1980: 200). The next sections examine whether the old age assistance portions of the Social Security bill did indeed permit older nonmarried women to remain in their own homes.

\section{Old Age Assistance}

This paper examines the decision to live with children or other relatives using state level data for 1940 and $1950 .^{8}$ I view this decision as a function of income and prices, including shadow prices. Thus many demographic variables, such as kin availability, can be thought of as affecting the shadow price. Because the decision of an older nonmarried woman to live with children or other relatives is really a joint decision reached between her and her children or relatives, I proxy for the income and prices faced both by nonmarried women and by their children or relatives.

The living arrangements decision can be described by three different models - a bargaining model which emphasizes the power relationships that determine the allocation of household resources, a voluntary mutual aid model, and an altruism model in which the welfare of the family is maximized by a household head. Under a bargaining model if an older nonmarried

\footnotetext{
${ }^{8}$ State level data is used both because the fraction of older, nonmarried women living with children is estimated from the census samples and cell sizes would be too small for state economic areas and because information on the average old age assistance payment is available only on the state level for both 1940 and 1950 .
} 
woman wishes to live with her children or relatives she might offer to pay them rent. In this model children with financial resources might exempt themselves from co-residence either through direct payments to their mothers or by inducing less well-off siblings to accept a trade of money for time by housing their mother. Under a mutal aid model older nonmarried women might provide babysitting or housekeeping services and in return they would share goods with scale economies, such as housing and durables. Rising children's income might cause them to buy services in the market instead of acquiring them through in-kind exchanges among family members. A government transfer to an older nonmarried woman might induce her to buy her own housing rather than move in with her children. In contrast, in an altruism model total family income, not individual income determines living arrangements. Government transfers to the elderly might therefore either wholly or partially displace children's transfers. ${ }^{9}$ If the transfer is relatively small then it might have either no or very little impact on the living arrangements of older women.

The living arrangements decision will also depend upon the rules of the Old Age Assistance program because these rules affect the shadow prices facing both the nonmarried woman and her relatives. I will therefore briefly describe the history of the Old Age Assistance program and its rules in the remainder of this section. ${ }^{10}$

The Social Security Act of 1935 included two programs targeting the elderly - Old Age Assistance (OAA), a need based program which made federal subsidies available to states with old age assistance programs, and Old Age Insurance, which in 1939 became Old Age and

\footnotetext{
${ }^{9}$ Although at most 10 percent of parents today receive transfers from their children (McGarry and Schoeni 1995), in 1937 between two-fifths and and half of the populatoin older than 64 may have been dependent upon friends and relatives (Shearon 1938).

${ }^{10}$ See Quadagno (1988), among others, for a history of the program.
} 
Survivors' Insurance (OASI). Less than 3 percent of aged widows benefited from Social Security survivors' benefits in the mid-1940s, but more than 30 percent from old age assistance. ${ }^{11}$ The average older widow had been widowed at age 55 and therefore, even if her husband had worked in a covered occupation, would not have been eligible for survivors' benefits. ${ }^{12}$

Prior to 1946 the federal government subsidized 50 percent of all OAA payments up to $\$ 30$ per month. After 1946, the federal government began to subsidize 80 percent of the first $\$ 25$ per month and 50 percent of all amounts above $\$ 25$, up to $\$ 30$ per month. This change in the subsidization formula led states to increase the average real benefit by 27 percent. In general, states with low benefits responded by raising benefits, whereas those with high benefits did not. Louisiana raised its real benefits by 122 percent, Florida and Texas by 80 percent, and Arkansas, Tennessee, and Washington by over 60 percent. In contrast, the largest increase in the high benefit states (California, Colorado, Massachusetts, Arizona, Conneticut, Nevada, and New York) was 21 percent and in one state (Arizona) real benefits fell by 5 percent.

Changing the federal subsidization formula also affected average recipiency rates. ${ }^{13}$ On average recipiency rates rose by only 9 percent, but the southern states, where average payments were low, increased their recipiency rates sharply. For example, in Louisiana the rate rose from 27 to 68 percent and in Georgia from 18 to 46 percent. In California, which paid the highest benefits,

\footnotetext{
${ }^{11}$ The total number of aged widow beneficiaries in 1944 was 69,000 (see Series H 230-237, U.S. Bureau of the Census 1975: 350) and the total number of aged widows in the population was 3,053,469 (see Series A 160-171, U.S. Bureau of the Census 1975: 350). In 1944 in states with an estimated widow population of 1,240,000, the total number of old age assitance recipients was 903,242, of which 53 percent were women (White and Hutton 1948). Of these women about four-fifths did not have a spouse present (Hanmer 1957).

${ }^{12}$ Age at which women were widowed was estimated from the 1950 census (Ruggles and Sobek 1995).

${ }^{13}$ Average recipiency rates are estimated as the total number of beneficiaries divided by the population older than 64.
} 
the recipiency rate rose from 26 percent to 30 percent. In Arizona, it fell by 2 percentage points. The increase in average recipiency rates in the south does not necessarily imply that southern programs became extremely generous. Often payments that had formerly been given to husbands and wives were now split between the two.

Although all state programs had to meet certain criteria to qualify for state funds, program rules varied by state. Persons were generally eligible for aid if their personal resources were less than a specified value, but the qualifying limit on the assessed value of real estate was more than three times as high in some states as in others. Many states, particularly those with high percentages of non-citizens, had citizenship requirements. States often held children legally responsible for the care of aged parents, using an income scale to determine whether and how much children should contribute. When children were financially able to contribute states granted assistance on a temporary basis pending an agreement to support or a court order. Relatives were required to reimburse the state for expenses that had already been made. In addition, states often had lien provisions as well, which provided for reimbursement from the recipient's estate for aid granted.

States also imposed residence requirements, but were limited by federal law which specified that no state could receive federal subsidies and set a requirement stipulating residence for more than five out of nine years immediately preceeding the application for assistance. In 1940 most states had the maximum residency requirement of five years, but by 1950 most required residence for only one year. Although officials in states with high benefits, such as California, often worried that the needy aged migrated from other states to receive benefits, studies of recipients in 
California found that there was no significant difference in length of residence between those who were on assistance and those who were not (Bond et al. 1954: 265). Migration of older women to different states was relatively rare. In 1940 only 3 percent of older nonmarried women had migrated to a different state between 1935 and 1940 and less than 2 percent had migrated between 1949 and 1950. I do not find a significant relationship between the increase in the fraction of a state's population that was older than 64 from 1940 to 1950 and the increase in average OAA payments.

Eligibility for old age assistance did not depend on living arrangements (Bond et al. 1954: 203), but the amount that old age assistance recipients received depended upon whether the recipient had any earnings, whether relatives were contributing, whether the recipient had any dependents, and whether the recipient was living with relatives or was living alone. Most recipients had no earnings. Sixty-one percent of recipients with no spouse had only OAA income. In 1944, when 74 percent of OAA recipients received no contributions from relatives and when 22 percent were living with relatives, the average monthly payment to those living alone was $\$ 35$ while the average monthly payment to those living with a son or daughter was $\$ 26$, to those living with another relative $\$ 29$, and to those living with a non-relative $\$ 32$. But, even though one-fifth of recipients were living with relatives, only five percent received shelter without cost. When recipients paid for shelter from relatives, OAA benefits were calculated assuming payments made for shelter (U.S. Social Security Board 1945). A visiting social worker determined the actual benefit amount after exploring the applicant's financial situation. ${ }^{14}$ Because all grants were determined on an

\footnotetext{
${ }^{14}$ The social worker examined the applicant's income and expenses, checked whether she was making full use of her financial resources, determined whether she could find appropriate work and earn enough to cover the difference
} 
Table 2: Percent Older Nonmarried Women Living with Family Members and Average OAA Payment

\begin{tabular}{lrr}
$\begin{array}{c}\text { 20th Percentile } \\
\text { of Average } \\
\text { OAA Payment }\end{array}$ & $\begin{array}{c}\text { Average Yearly } \\
\text { OAA Payment } \\
(1940 \$)\end{array}$ & $\begin{array}{c}\text { \% Living with } \\
\text { Family Members } \\
\text { as Dependent }\end{array}$ \\
\hline 1 (bottom) & 133.77 & 51.10 \\
2 & 208.78 & 44.63 \\
3 & 263.63 & 40.13 \\
4 & 309.64 & 41.81 \\
5 (top) & 386.76 & 38.52 \\
\hline
\end{tabular}

Note. The average OAA payment was adjusted for state cost of living.

individual basis and no use was made of published payment schedules, I use the average of state payments to all recipients, both male and female, married and nonmarried..$^{15}$

In states with the lowest OAA payments, the proportion of nonmarried women living with their relatives was highest (see Table 2). At low benefit levels, the proportion living with family members fell sharply with increased benefits, but then levelled off with additional increases. Table 2 implies that the level of OAA benefits determined OAA living arrangements. But, the states with the lowest payments were the southern and border states, suggesting that state characteristics, not average OAA payments might be driving factor. I therefore control for state characteristics.

between income and all expenses deemed necessary, judged whether there were special needs (e.g. medical) and then made a recommendation as to the amount of the grant which later had to be approved by the case supervisor and director (Bond et al. 1954: 202-205).

${ }^{15}$ Separate breakdowns are unavailable. 


\section{OAA and Living Arrangements}

In estimating the impact of Old Age Assistance payments on the probability of living with children, I account for state characteristics in three ways. I estimate a difference equation, or a fixed effects model, under the assumption that the characteristics of states that led them to have higher proportions of nonmarried women living with family members were permanent, not transitory features of the state. I also estimate an ordinary least squares model and a random effects model in which I directly model state and program characteristics and thus am able to quantify the impact of factors other than OAA on the living arrangements of older nonmarried women.

I assume that the fraction of older nonmarried women within state $i$ at time $t, f_{i t}, t=$ 1940,1950 , is a function of the $\log$ of average OAA payments within the state $\left(\ln \left(O A A_{i t}\right)\right)$, the average recipiency rate $\left(R R_{i t}\right)$, and a vector of state characteristics, $X_{i t}$, such as pension program rules, the number of children and their income, and education. ${ }^{16}$ This yields,

$$
f_{i t}=\beta_{0}+\beta_{1} \ln \left(O A A_{i t}\right)+\beta_{2} R R_{i t}+\beta_{3} X_{i t}+u_{i t}
$$

where $u_{i t}$ is an error term. Setting $\beta_{3}$ equal to zero, or assuming that state characteristics are constant across time, the estimation equation for the first difference equation can be written as

$$
f_{1950}-f_{1940}=\beta_{1}\left(\ln \left(O A A_{1950} / O A A_{1940}\right)+\beta_{2}\left(R R_{1950}-R R_{1940}\right)+\left(u_{1950}-u_{1940}\right)\right.
$$

or

$$
\Delta f_{1950-1940}=\beta_{1} \Delta \ln \left(O A A_{1950-1940}\right)+\beta_{2} \Delta R R_{1950-1940}-u_{1950-1940},
$$

\footnotetext{
${ }^{16}$ Table 2 illustrates that the logarithm of averagc OAA payments most accurately describes the relation between the fraction of women living with family members and average OAA payments.
} 
where $u_{i}$ is a randomly distributed error term that is uncorrelated with OAA. The coefficients $\beta_{1}$ and $\beta_{2}$ can be interpreted as the effect of a percent change in average OAA payments and recipiency rates on the fraction of older nonmarried women living with family members. The assumption that the characteristics of states that led them to have higher proportions of nonmarried women living family members were permanent is not unreasonable. With the exception of residency requirements, which were unlikely to affect a population as nonmigratory as older nonmarried women, program rules did not change between 1940 and 1950. However, when the federal government changed the formula determining the subsidization of Old Age Assistance in 1946, real bencfits and average recipiency rates increased sharply in the poorer states.

Rather than estimating a difference equation I could pool the years 1940 and 1950, and estimate the first equation using ordinary least squares. Allowing for state specific effects, the model can be reformulated as

$$
f_{i t}=\beta_{0}+\beta_{1} \ln \left(O A A_{i t}\right)+\beta_{2} R R_{i t}+\beta_{3} X_{i t}+\epsilon_{i}+u_{i t}
$$

where $\epsilon_{i}$ is the random disturbance characterizing state $i$ and is constant through time. $\Lambda$ ssuming that the individual effects are uncorrelated with the other regressors, the estimated coefficients will be consistent.

Among the control variables included in the vector $X_{i t}$ are dummies for program rules (whether a state had a relatives' responsibility law, whether a state had a lien law, and whether a state had a citizenship law) and a dummy for whether county funds were used for OAA bencfits. ${ }^{17}$ Because counties were more likely than states to run out of money and temporarily suspend payments,

\footnotetext{
${ }^{17}$ The data sources used in constructing all variables are given in Appendix B.
} 
OAA benefits funded through county funds were not always a reliable source of payments. Also included in the vector $X_{i t}$ is the percentage of older nonmarried women who were white, an indicator of higher income, and the percentage foreign-born, an indicator both of lower income and of different cultural traditions. Another indicator of low income included in the vector $X_{i t}$ is the fraction of older nonmarried women with less than an elementary school education. The percentage of the labor force that was employed in agriculture is another control variable, because prior to 1950 households containing nonmarried women who had moved in with family members were most likely to be farm households. The vector $X_{i t}$ also contains a variable giving average wage income of household heads aged 25 to 44 , an indicator of children's wage income. The final control variable is the ratio of women aged 35 to 44 to women older than 64 , an indicator of the number of "daughters" available to care for older "mothers." Moves to children's homes circa 1940 were relatively short and may be indicative of unwillingness to move long distances. ${ }^{18}$ The daughter-mother ratio will be determined by fertility, life expectancy at older ages, and migration into and out of the state.

Table 3 presents the results from the first difference equation, the pooled OLS equation, and the random effects model. The first difference equation implies that a 27 percent increase in average OAA benefits, such as occurred between 1940 and 1950 , decreased the probability that a nonmarried woman would be living with her children by 1.5 percentage points and implies an elasticity of -0.13 . The results were similar when the recipiency rate is excluded (the coefficient on average OAA payments increases slightly to -0.063 ), but the results were very sensitive to

\footnotetext{
${ }^{18}$ Three-quarters of the nonmarried women older than 64 living in the households of children or relatives who had migrated between 1935 and 1940 had lived in the same county in 1935 and another 10 percent in a different county within the same state.
} 
Table 3: First Difference Equation, Pooled OLS, and Random Effects Model, with Percentage Older Nonmarried Women Living with Family Members as the Dependent Variable

\begin{tabular}{|c|c|c|c|c|c|c|}
\hline \multirow{2}{*}{$\frac{\text { Variable }}{\overline{\bar{\Delta} \text { fraction living with family }}}$} & \multirow{2}{*}{ 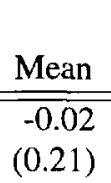 } & $\begin{array}{c}\text { Difference } \\
\text { Equation } \\
\end{array}$ & \multicolumn{2}{|c|}{$\begin{array}{l}\text { Pooled } \\
\text { OLS }\end{array}$} & \multicolumn{2}{|c|}{$\begin{array}{l}\text { Random } \\
\text { Effects }\end{array}$} \\
\hline & & & & & & \\
\hline$\Delta \ln (\mathrm{OAA})$ & $\begin{array}{r}0.28 \\
(0.73)\end{array}$ & $\begin{array}{l}-0.057^{\dagger} \\
(0.023)\end{array}$ & & & & \\
\hline$\Delta$ recipiency rate & $\begin{array}{r}0.02 \\
(0.43)\end{array}$ & $\begin{array}{r}-0.044 \\
(0.069)\end{array}$ & & & & \\
\hline Fraction living with family & $\begin{array}{r}0.43 \\
(0.07)\end{array}$ & & & & & \\
\hline Intercept & & & $\begin{array}{r}0.756^{\ddagger} \\
(0.213)\end{array}$ & $\begin{array}{c}0.955^{\ddagger} \\
(0.214)\end{array}$ & $\begin{array}{r}0.780^{\ddagger} \\
(0.235)\end{array}$ & $\begin{array}{r}0.982^{\ddagger} \\
(0.235)\end{array}$ \\
\hline $\ln (\mathrm{OAA})$ & $\begin{array}{r}5.50 \\
(0.38)\end{array}$ & & $\begin{array}{l}-0.060^{\dagger} \\
(0.024)\end{array}$ & $\begin{array}{l}-0.090^{\ddagger} \\
(0.027)\end{array}$ & $\begin{array}{l}-0.062^{\dagger} \\
(0.026)\end{array}$ & $\begin{array}{l}-0.094^{\ddagger} \\
(0.028)\end{array}$ \\
\hline Recipiency rate & $\begin{array}{r}0.24 \\
(0.11)\end{array}$ & & $\begin{array}{l}-0.092^{*} \\
(0.055)\end{array}$ & $\begin{array}{r}-0.084 \\
(0.057)\end{array}$ & $\begin{array}{r}-0.058 \\
(0.060)\end{array}$ & $\begin{array}{r}-0.055 \\
(0.057)\end{array}$ \\
\hline Dummy $=1$ if & & & & & & \\
\hline Relative responsibility law & $\begin{array}{r}0.55 \\
(0.50)\end{array}$ & & $\begin{array}{r}0.010 \\
(0.013)\end{array}$ & $\begin{array}{r}-0.419 \\
(0.199)\end{array}$ & $\begin{array}{r}0.006 \\
(0.014)\end{array}$ & $\begin{array}{l}-0.420^{\ddagger} \\
(0.153)\end{array}$ \\
\hline Lien law & $\begin{array}{r}0.43 \\
(0.50)\end{array}$ & & $\begin{array}{l}0.023^{*} \\
(0.012)\end{array}$ & $\begin{array}{c}0.026^{\dagger} \\
(0.012)\end{array}$ & $\begin{array}{c}0.025^{*} \\
(0.014)\end{array}$ & $\begin{array}{c}0.024^{*} \\
(0.014)\end{array}$ \\
\hline Citizenship law & $\begin{array}{r}0.66 \\
(0.48)\end{array}$ & & $\begin{array}{r}-0.011 \\
(0.010)\end{array}$ & $\begin{array}{r}-0.011 \\
(0.009)\end{array}$ & $\begin{array}{r}-0.008 \\
(0.011)\end{array}$ & $\begin{array}{r}-0.008 \\
(0.011)\end{array}$ \\
\hline Financed by county funds & $\begin{array}{r}0.47 \\
(0.50)\end{array}$ & & $\begin{array}{r}0.012 \\
(0.010)\end{array}$ & $\begin{array}{r}0.008 \\
(0.009)\end{array}$ & $\begin{array}{r}0.010 \\
(0.011)\end{array}$ & $\begin{array}{r}0.008 \\
(0.011)\end{array}$ \\
\hline $\ln (\mathrm{OAA}) *($ relative responsibility law $)$ & $\begin{array}{r}3.10 \\
(2.82)\end{array}$ & & & $\begin{array}{c}0.070^{\ddagger} \\
(0.024)\end{array}$ & & $\begin{array}{r}0.078^{\ddagger} \\
(0.028)\end{array}$ \\
\hline Fraction older nonmarried women & & & & & & \\
\hline White & $\begin{array}{r}0.91 \\
(0.12)\end{array}$ & & $\begin{array}{c}-0.236^{\ddagger} \\
(0.073)\end{array}$ & $\begin{array}{c}-0.219^{\ddagger} \\
(0.070)\end{array}$ & $\begin{array}{l}-0.234^{\ddagger} \\
(0.080)\end{array}$ & $\begin{array}{c}-0.217^{\ddagger} \\
(0.076)\end{array}$ \\
\hline Foreign-born & $\begin{array}{r}0.20 \\
(0.15)\end{array}$ & & $\begin{array}{r}0.030 \\
(0.046)\end{array}$ & $\begin{array}{r}0.025 \\
(0.044)\end{array}$ & $\begin{array}{r}0.011 \\
(0.053)\end{array}$ & $\begin{array}{r}0.009 \\
(0.050)\end{array}$ \\
\hline Never finished elementary school & $\begin{array}{r}0.45 \\
(0.16)\end{array}$ & & $\begin{array}{r}0.098 \\
(0.062)\end{array}$ & $\begin{array}{r}0.087 \\
(0.059)\end{array}$ & $\begin{array}{r}0.086 \\
(0.067)\end{array}$ & $\begin{array}{r}0.074 \\
(0.063)\end{array}$ \\
\hline Fraction labor force agricultural & $\begin{array}{r}0.19 \\
(0.13)\end{array}$ & & $\begin{array}{r}-0.055 \\
(0.056)\end{array}$ & $\begin{array}{r}-0.067 \\
(0.054)\end{array}$ & $\begin{array}{r}-0.057 \\
(0.062)\end{array}$ & $\begin{array}{r}-0.068 \\
(0.059)\end{array}$ \\
\hline Daughter-mother ratio & $\begin{array}{r}1.87 \\
(1.86)\end{array}$ & & $\begin{array}{r}0.016 \\
(0.016)\end{array}$ & $\begin{array}{r}0.023 \\
(0.015)\end{array}$ & $\begin{array}{r}0.017 \\
(0.017)\end{array}$ & $\begin{array}{r}0.023 \\
(0.016)\end{array}$ \\
\hline ln(wage income heads 25-44) & $\begin{array}{r}7.08 \\
(0.27)\end{array}$ & & $\begin{array}{r}0.020 \\
(0.025)\end{array}$ & $\begin{array}{r}0.011 \\
(0.024)\end{array}$ & $\begin{array}{r}0.017 \\
(0.026)\end{array}$ & $\begin{array}{r}0.010 \\
(0.025)\end{array}$ \\
\hline Dunnmy $=1$ if year is 1950 & $\begin{array}{r}0.50 \\
(0.50)\end{array}$ & & $\begin{array}{r}-0.000 \\
(0.011)\end{array}$ & $\begin{array}{r}-0.000 \\
(0.011)\end{array}$ & $\begin{array}{r}-0.008 \\
(0.012)\end{array}$ & $\begin{array}{r}-0.004 \\
(0.012)\end{array}$ \\
\hline Adjusted/Overall $\mathrm{R}^{2}$ & & 0.16 & 0.62 & 0.66 & 0.60 & 0.64 \\
\hline Observations & & 48 & 96 & 96 & 96 & 96 \\
\hline
\end{tabular}

Note. All regressions are weighted with weights proportional to the number of nonmarried older women within a state. OAA is the average yearly payment in 1940 dollars, adjusted for state cost of living in the pooled OLS and random effects model. Standard errors are in parentheses. The symbols $*, \dagger$, and $\ddagger$ indicate that the coefficient is significantly different from 0 at at least the 10 percent, 5 percent, and 1 percent level, respectively. 
inclusion of other variables, such as the first difference of state income, the daughter-mother ratio, or of the percent in agriculture and tests revealed that multicollinearity was a problem. However, the exclusion of first differences in children's income and in the mother-daughter ratio could lead to specification bias because these variables changed over time. Fortunately, multicollinearity was not a problem in either the pooled OLS regression or the random effects model and these specifications yielded coefficients on average OAA payments that were robust to the inclusion of other control variables, including region of residence (not shown). The coefficient on average OAA payment did however fall somewhat as control variables were added. Both models imply that OAA income was an important determinant of living arrangements, with a standard deviation increase leading to a more than 2 percentage point increase in the fraction living with family members. Both models also predict that the 27 percent increase in average OAA benefits between 1940 and 1950 reduced the probability that nonmarried women would be living with their children by at least 1.2 percentage points, implying an elasticity of -0.10 .

The impact of decreasing Old Age Assistance payments varied according to whether a state had a relatives' responsibility law. In states with no such law, a 27 percent increase in OAA benefits reduced the probability that a nonmarried woman would be living with her relatives by at least 1.8 percentage points, implying an elasticity of -0.16 , whereas in states with such a law the probability fell by only 0.4 percentage points, implying an elasticity of -0.03 . In a state which paid average benefits, the proportion of older nonmarried women living with relatives was 3 percentage points lower than in a state without such a law. ${ }^{19}$

\footnotetext{
${ }^{19}$ Because relatives' responsibility laws were relatively rare in the southern and border states, the presence of a relatives' responsibility law may reflect other state characteristics.
} 
The recipiency rate had a small and statistically insignificant effect on living arrangements, a standard deviation increase in the recipiency rate decreasing the probability that an older nonmarried woman would be living with her relatives by 0.9 to 1.0 percentage points. The coefficient on an interaction term between a high recipiency rate and OAA payments was small and statistically insignificant, perhaps because the recipiency rate was not that for nonmarried women. In southern states where OAA payments to husbands and wives were split after 1946, the average recipiency rate is especially likely to be a poor indicator of the recipiency rate of nonmarried women.

Lien laws raised the probability that an older, nonmarried women would be living with her relatives by about two and a half percentage points, suggesting that women who had property to bequeath, however small, may have preferred to live with their children (and the children may have preferred to have their mothers live with them) rather than accept OAA and have the state attach a lien for the value of OAA received to the property upon their death. Other program rules were relatively unimportant. Citizenship laws had a negative and insignificant impact on the probability of living with family members. Because mainly nonsouthern states had citizenship laws, this variable as well may reflect state characteristics. Whether a state had high residency requirements (not shown) had a small and insignificant impact on living arrangements, perhaps because so few women were likely to be migrants at older ages. If old age assistance payments were financed by county funds, and hence were more likely to be paid irregularly, then the probability of women living with their children increased by about 1 percentage point. When the average recipiency rate is excluded from the specification the probability rises to 2 percentage 
points and becomes statistically significant.

The percentage of the population of older nonmarried women that was white had a very large and significant impact on living arrangements; an increase of a standard deviation decreased the probability of an unmarried woman living with family members by almost 3 percentage points. The greater the percentage foreign-born the more likely a woman was to live with her family. The percentage of the labor force within a state employed in agriculture had a small, negative, and statistically insignificant impact on the probability that a woman would live with her family. However, when the percentage of the labor force in agriculture is the only regressor, the coefficient on the fraction employed in agriculture is positive and significant. But, as soon as I control for state income, the coefficient becomes insignificant. When I control for average OAA payments, the coefficient becomes negative.

Among the characteristics of children that I included in the specification were their number within the state, as proxied by the daughter-mother ratio, and their income, as proxied by average wage income for household heads age 25 to 44 . The daughter-mother ratio was not a statistically significant predictor of living arrangements, but a standard deviation increase did lead to a 4.3 percentage point increase in the fraction of nonmarried women living with family members. A decline of 0.3 in the daughter-mother ratio, as occurred between 1940 and 1950, would decrease the proportion of nonmarried women living with family members by 0.7 percentage points. When education is excluded from the specification the coefficient becomes slightly larger and statistically significant. Similarly when the daughter-mother ratio is excluded the coefficient on education becomes somewhat larger and statistically significant, suggesting that it is difficult to 
distinguish between demographic and wealth factors. Other measures of fertility and mobility, such as the total number of children born to women older than 64 and a "highly mobile" variable, based on the percentage of individuals within a state who had moved in the past 5 years in 1940 and in the past year in 1950 , had no predictive power.

The wage income of children was a positive, but small and insignificant, predictor of living with family members. When this variable was the only regressor it was a negative and significant predictor, perhaps because states with higher average incomes also had higher average OAA payments. The wage income of children becomes a significantly positive predictor of living with family members as soon as I add average OAA payments to the specification, but then becomes insignificant when all dummies describing program rules are added to the specification. Although the results are not that robust, they suggest that as the incomes of children increase, they are more likely to welcome their parents into their homes, a result consistent with the finding of Börsch-Supan (1989) that in recent times children who receive their parents into their homes have about twice the average income of all child households. ${ }^{20}$ The coefficients on OAA payments and education imply that as parents' income rises, parents are less likely to move in with their children. The net outcome depends on whether parents' income is large enough to outweigh the impact of childrens' income. ${ }^{21}$

A potential problem with the estimates presented in Table 3 is measurement error in average Old Age Assistance payments because I am forced to use state averages for all recipients, male

\footnotetext{
${ }^{20}$ One possible explanation is that as children's income rises, they acquire larger houses. Wealthier children might also be repaying their parents for education expenses or for the inheritance of property.

${ }^{21}$ I also investigated whether the existing housing stock within the state, as proxied by the rent increase in going from a one bedroom to a two, three, and four hedroom house in 1960, had an impact on elderly living arrangements. It did not.
} 
and female, married and unmarried. In addition, another potential problem is endogeneity created by variable construction. Because individuals on the Old Age Assistance rolls received lower payments if they were living with family members, the average OAA payment within a state may be low because many individuals are living with their family members. ${ }^{22}$ Of course, if the factors inducing high coresidency rates are permanent features of the state, then the first difference equation will still yield unbiased estimates. If they are not, then this endogeneity problem, as well as the measurement problem, is readily resolved through the use of an instrumental variable. In the case of the pooled OLS equation, an instrumental variable must be used as well. The instrument that I use is the average payment made to households under $\Lambda \mathrm{id}$ to Families with Dependent Children (AFDC). This variable is a proxy for taste for welfare expenditures, and it, or its first difference, is highly correlated with average OAA payments $(\rho=0.66)$. It is arguably uncorrelated with the error term in either the first difference, pooled OLS, or random effects equation. In the case of the random effects model, I can obtain instrumental variables estimates for all time varying covariates using second step feasible gencralized least squares estimation (Hsiao 1986: 100-104). When I instrument, the coefficients on average OAA payments and their standard errors rise (see Table 4). Although a Hausman test rejects the hypothesis of endogeneity of OAA payments at the 20 percent level of significance, because of the size of the standard errors I cannot rule out that endogeneity is not a problem.

The instrumented first difference equation implies that a 27 percent increase in average OAA payments lowers the fraction of older nonmarried women living with their relatives by 1.9

\footnotetext{
${ }^{22}$ In contrast, a variable such as the recipiency rate presents fewer endogeneity problems, because recipiency depended on income, not living arrangements.
} 
Table 4: IV Estimates of Difference Equation, Pooled OLS, and Random Effects Models Using Average AFDC Payment as an Instrument

\begin{tabular}{|c|c|c|c|c|}
\hline \multirow{2}{*}{ 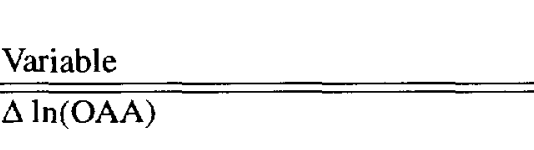 } & \multirow{2}{*}{$\begin{array}{r}\begin{array}{c}\text { Difference } \\
\text { Equation }\end{array} \\
\begin{array}{r}-0.070^{\mp} \\
(0.027)\end{array}\end{array}$} & \multicolumn{2}{|c|}{$\begin{array}{c}\text { Pooled } \\
\text { OLS }\end{array}$} & \multirow[t]{2}{*}{$\begin{array}{l}\text { Random } \\
\text { Effects }\end{array}$} \\
\hline & & & & \\
\hline$\Delta$ recipiency rate & $\begin{array}{r}-0.027 \\
(0.072)\end{array}$ & & & \\
\hline Intercept & & $\begin{array}{c}1.159^{\ddagger} \\
(0.430)\end{array}$ & $\begin{array}{c}1.187^{\ddagger} \\
(0.387)\end{array}$ & $\begin{array}{r}1.397^{\ddagger} \\
(0.007)\end{array}$ \\
\hline $\ln (\mathrm{OAA})$ & & $\begin{array}{l}-0.164^{*} \\
(0.097)\end{array}$ & $\begin{array}{l}-0.147^{\dagger} \\
(0.084)\end{array}$ & $\begin{array}{l}-0.166^{\dagger} \\
(0.077)\end{array}$ \\
\hline Recipiency rate & & $\begin{array}{r}0.042 \\
(0.133)\end{array}$ & $\begin{array}{r}-0.015 \\
(0.113)\end{array}$ & $\begin{array}{r}0.071 \\
(0.149)\end{array}$ \\
\hline \multicolumn{5}{|l|}{ Dummy $=1$ if } \\
\hline Relative responsibility law & & $\begin{array}{r}0.027 \\
(0.021)\end{array}$ & $\begin{array}{c}-0.419^{\dagger} \\
(0.199)\end{array}$ & \\
\hline Lien law & & $\begin{array}{r}0.025 \\
(0.014)\end{array}$ & $\begin{array}{c}0.027^{\dagger} \\
(0.012)\end{array}$ & \\
\hline Citizenship law & & $\begin{array}{r}-0.013 \\
(0.011)\end{array}$ & $\begin{array}{r}-0.011 \\
(0.010)\end{array}$ & \\
\hline Financed by county funds & & $\begin{array}{c}0.023^{*} \\
(0.015)\end{array}$ & $\begin{array}{r}0.014 \\
(0.013)\end{array}$ & \\
\hline $\ln (\mathrm{OAA})^{*}($ relative responsibility law $)$ & & & $\begin{array}{c}0.079^{\dagger} \\
(0.036)\end{array}$ & \\
\hline Fraction older nonmarried women & & & & \\
\hline White & & $\begin{array}{c}-0.154^{*} \\
(0.109)\end{array}$ & $\begin{array}{l}-0.175^{*} \\
(0.095)\end{array}$ & $\begin{array}{r}-0.180 \\
(0.169)\end{array}$ \\
\hline Foreign-born & & $\begin{array}{r}0.079 \\
(0.067)\end{array}$ & $\begin{array}{r}0.049 \\
(0.058)\end{array}$ & $\begin{array}{r}0.187 \\
(0.181)\end{array}$ \\
\hline Never finished elementary school & & $\begin{array}{r}-0.006 \\
(0.107)\end{array}$ & $\begin{array}{r}0.039 \\
(0.092)\end{array}$ & $\begin{array}{r}0.005 \\
(0.134)\end{array}$ \\
\hline Fraction labor force agricultural & & $\begin{array}{r}-0.086 \\
(0.068)\end{array}$ & $\begin{array}{r}-0.085 \\
(0.061)\end{array}$ & $\begin{array}{r}-0.049 \\
(0.374)\end{array}$ \\
\hline Daughter-mother ratio & & $\begin{array}{r}0.017 \\
(0.017)\end{array}$ & $\begin{array}{r}0.024 \\
(0.016)\end{array}$ & $\begin{array}{c}0.066^{*} \\
(0.040)\end{array}$ \\
\hline ln(wage income heads $25-44$ ) & & $\begin{array}{r}0.030 \\
(0.029)\end{array}$ & $\begin{array}{r}0.015 \\
(0.026)\end{array}$ & $\begin{array}{r}-0.012 \\
(0.056)\end{array}$ \\
\hline Dummy $=1$ if year is 1950 & & $\begin{array}{r}0.020 \\
(0.022)\end{array}$ & $\begin{array}{r}0.010 \\
(0.019)\end{array}$ & \\
\hline Adjusted $\mathrm{R}^{2}$ & 0.15 & 0.58 & 0.63 & \\
\hline Observations & 48 & 96 & 96 & 96 \\
\hline
\end{tabular}

Note. See the notes to Table 3. The logarithm of the average AFDC payment was used an instrument for $\ln (\mathrm{OAA})$ and the logarithm of the average AFDC payment interacted with whether a statc had a relatives' responsibility law as the instrument for $\ln (\mathrm{OAA}) *$ (relative responsibility law). Instrumental variables in the random effects framework were derived using second step feasible gencralized lcast squarcs cstimatcs. To ensure matrix invertibility variables were restricted to time varying covariates. All regressions are weighted with weights proportional to the number of nonmarried older women within a state. Standard errors are in parentheses. The symbols $*$, $\dagger$, and $\ddagger$ indicate that the coefficient is significantly different from 0 at at least the 10 percent, 5 percent, and 1 percent level, respectively. 
percentage points. When average OAA payment is not interacted with an indicator for whether a state had a relatives' responsibility law, a 27 percent increase in average OAA payments raises the probability of coresidence by 3.3 percentage points in both the pooled OLS and the random effects model, implying an elasticity of -0.28 . The pooled OLS equation implies that in states without a relatives' responsibility law the probability falls by 2.9 percentage points, implying an elasticity of -0.25 , and in a state with such a law by 1.3 percentage points, implying an elasticity of -0.11 .

The endogeneity problems are potentially even more complex. States may decide average OAA payments, recipiency rates, and program rules based upon the percentage of the elderly likely to be in need and those living with family members may have been judged to be either more or less in need. If so, then most of the independent variables are endogenous, and I do not have enough instruments to calculate instrumental variables estimates. I can however run the same specifications on a sample of widows aged 50 to 64 who would be ineligible for OAA because of their age, but who would be likely to live with relatives if that was the state norm. When I do so, the impact of average OAA payments becomes much smaller and is insignificant. ${ }^{23}$

Figure 1 implied that Old Age Assistance payments mainly had an impact on the living arrangements of nonmarried women. In fact, in a sample of married women older than 64 the coefficient on average Old Age Assistance payments is one sixth the size of the coefficient in the sample of nonmarried women, suggesting that nonmarried women, and hence widows, were

\footnotetext{
${ }^{23}$ The coefficient on the first difference equation falls to -0.031 and is insignificant. The coefficient on the pooled OLS equation, when OAA is not interacted with whether a state had a relatives' responsibility law, falls to -0.019 and is insignificant. When whether a state had a relatives' responsibility law is interacted with OAA payments, the coefficient on OAA payments falls to -0.046 and the coefficient on the interaction term to -0.044 . Both coefficients are insignificant.
} 
indeed the primary beneficiaries of Social Security. ${ }^{24}$

\section{Implications}

I have shown that in 1940 and 1950 income was one of the major determinants of the living arrangements of older nonmarried women. The 27 percent increase in average OAA benefits between 1940 and 1950 lowered the proportion of older nonmarried women living with family members by 1.2 to 1.5 percentage points, thereby explaining most of the 1.6 percentage point decrease in the percentage of older nonmarried women living with family members. Other important determinants of living arrangements within the 1940-1950 cross-section were program rules, the recipiency rate for OAA, race, education, and the ratio of "daughters" to "mothers." But, of these factors, only the daughter-mother ratio could account for part of the 1940-1950 decline in the proportion of older nonmarried women living with family members. Interestingly, children's income increased the probability that nonmarried women would live with family members, suggesting that as children's income rises children are more likely to welcome their parents into their homes. In contrast, the results for OAA benefits and for education imply that as parents' income rises, parents are less likely to move in with children.

Estimates of the impact of Old Age Assistance on living arrangements in the absence of relatives' responsibility laws can be used to cstimate the effect of the increase in Social Security income and in recipiency rates on the decline in the fraction of older nonmarried women living with family members from 1950 to 1990 . These imply that almost half of the actual decline in

\footnotetext{
${ }^{24}$ The coefficient on OAA in the first difference equation falls to -0.015 and is insignificant.
} 
the fraction of older nonmarried women living with family members can be attributed to rising Social Security benefits and expanded eligibility, with most of this increase attributable to benefit increases. ${ }^{25}$ My results are consistent with the lower bound estimate of Michael et al. (1980) that 46 percent of the actual 1950-1976 increase in widows' propensity to live alone was due to rising Social Security income. They are, however, below their upper bound estimate of 84 percent. My finding that the fraction of women living with family members is related to the logarithm of average OAA payments is also consistent with Börsch-Supan's (1989) result of a strong income effect for elderly at low levels of income and a small one at high levels. ${ }^{26}$

My findings also suggest that Social Security had a substantial impact on the living arrangements of older nonmarried women because it came with no strings attached. Had the 1950-1990 benefit increase been accompanied by the adoption of relatives' responsibility laws, the predicted increase in the fraction of nonmarried women living with family members would be one fifth of the predicted increase in the absence of such laws. ${ }^{27}$

Although numerous studies have documented the importance of kin availability to living arrangements within a single cross-section (e.g. Kobrin 1976; Wolf 1995), kin availability accounts for only a small portion of the decline in the proportion of nonmarried women living

\footnotetext{
${ }^{25}$ In 199084 percent of nonmarried women older than 64 were receiving an average Social Security income of $\$ 5972$, a 122 percent real increase over the average OAA payment. Using the random effects model, 42 percent of the decline in coresidence could be attributed to Social Security, with 70 percent of the 42 percent attributable to increasing benefits. Using the IV estimates, 49 percent could be attributed to Social Security, with 93 percent of the 49 percent attributable to increasing benefits.

${ }^{26}$ In contrast, Michael et al. (1980) found that the income effect was small at low levels, then rose at intermediate levels, and then became small again. Schwartz et al. (1984) and Börsch-Supan et al. (1992) found that increasing the income of the elderly did not raise their probability of living alone relative to the probability of living with their children, but it is not clear if they tested for nonlinearities.

${ }^{27}$ In the absence of relatives' responsibility laws a 122 percent benefit increase decreased the proportion of women living with family members by 7.5 percentage points. With such laws the probability would be decreased by 1.6 percentage points.
} 
with family members. Michael et al. (1980) find that a decline in kin availability could explain at most 10 percent of the actual increase in widows' propensity to live alone between 1950 and 1976. I find that kin availability explains only 7 percent of the actual $1950-1990$ decline in nonmarried women's propensity to live with family members. The impact of the other variables in my cross-section is also relatively small. All variables, including Social Security, accounted for only 60 percent of the actual decline.

Several factors may account for the portion of the 1950-1990 decline in the fraction of older nonmarried women living family members that is unexplained by the cross-sectional estimates. Although in recent data most health variables, with the exception of those indicating a severe disability, such as difficulty in meal preparation, money management, and phone use, are not associated with the probability of living alone (Wolf 1990), improvements in health combined with the development of assisted living communities and of private and state social support services may be enabling more of the elderly to live on their own. The price of independent living may now have fallen because of the growth of single portion food products, the growth of housing for single individuals and of retirement communities in low cost living areas, and the declining price of transport and of communication with family members. The rise in women's lahor force participation may have increased married couples' child-care demands and therefore made living with children relatively less attractive. Demand for privacy may also have increased, both on the part of the children and of the mothers or other relatives.

My findings suggest that the proportion of older nonmarried women living with children or other relatives is likely to continue to trend downwards. This is particularly likely if, as the 
Technical Panel of the 1994-1995 Social Security Advisory Council suggested, mechanisms are implemented to raise the ratio of survivor to couples benefits. But, even if the early age of entitlement for widows benefits were increased, the proportion of widows living with children or other relatives may continue to fall if elderly health improves, the price of single living declines, or demand for privacy increases. 
Table 5: Living Arrangements of Women Older than 64 by Marital Status

\begin{tabular}{|c|c|c|c|c|c|c|c|c|c|c|c|c|}
\hline & \multicolumn{4}{|c|}{$\%$ Household Head or Wife of } & \multicolumn{4}{|c|}{$\%$ With Family as Dependent } & \multicolumn{4}{|c|}{$\%$ Other (Boarder, etc) } \\
\hline Year & All & $\begin{array}{l}\text { Mar- } \\
\text { ried }\end{array}$ & $\begin{array}{l}\text { Wid- } \\
\text { owed }\end{array}$ & Other & All & $\begin{array}{c}\text { Mar- } \\
\text { ried }\end{array}$ & $\begin{array}{l}\text { Wid- } \\
\text { owed }\end{array}$ & Other & All & $\begin{array}{l}\text { Mar- } \\
\text { ried }\end{array}$ & $\begin{array}{l}\text { Wid- } \\
\text { owed }\end{array}$ & Other \\
\hline 1880 & 53.4 & 88.6 & 36.0 & 21.1 & 40.6 & 10.1 & 56.7 & 59.0 & 6.0 & 1.2 & 7.3 & 20.0 \\
\hline 1900 & 55.4 & 87.3 & 40.2 & 29.1 & 39.6 & 11.5 & 54.1 & 50.5 & 5.0 & 1.2 & 5.8 & 20.4 \\
\hline 1910 & 56.7 & 87.6 & 42.1 & 25.5 & 38.8 & 10.8 & 53.4 & 55.9 & 4.4 & 1.5 & 4.5 & 18.6 \\
\hline 1920 & 57.5 & 89.3 & 41.9 & 32.2 & 38.2 & 9.0 & 53.6 & 51.4 & 4.4 & 1.7 & 4.5 & 16.5 \\
\hline 1940 & 63.9 & 90.7 & 51.0 & 40.5 & 30.6 & 7.5 & 43.3 & 41.3 & 5.5 & 1.8 & 5.7 & 18.2 \\
\hline 1950 & 65.4 & 92.3 & 52.0 & 45.1 & 28.8 & 6.2 & 41.7 & 38.9 & 5.9 & 1.6 & 6.8 & 16.1 \\
\hline 1960 & 75.6 & 96.5 & 65.3 & 65.1 & 19.8 & 3.4 & 28.6 & 25.0 & 4.7 & 0.2 & 6.2 & 9.9 \\
\hline 1970 & 80.1 & 96.7 & 71.9 & 63.5 & 17.4 & 2.3 & 25.8 & 28.3 & 2.5 & 1.0 & 2.3 & 8.3 \\
\hline 1980 & 88.5 & 97.9 & 83.0 & 80.2 & 10.9 & 1.8 & 16.2 & 18.0 & 0.6 & 0.3 & 0.7 & 1.7 \\
\hline 1990 & 89.4 & 97.6 & 85.3 & 78.2 & 9.1 & 1.9 & 13.5 & 16.0 & 1.5 & 0.5 & 1.2 & 5.8 \\
\hline
\end{tabular}

Note. Restricted to the noninstitutionalized. The majority of women living in "other" households were boarders and lodgers. A few were domestic employees. Estimated from the integrated public use census samples (Ruggles and Sobek 1995).

\section{Appendix A}

Table 5 provides a detailed breakdown of trends in older women's living arrangements Note that whereas in the past even widows who headed their own households were likely to have children present, today most nonmarried women head their own independent households and widowed women are unlikely to have any of their own children in the household. ${ }^{28}$ The proportion of nonmarried women heading their own independent households increased even though the labor force participation rates of these women fell slightly from around 16 percent in 1910 to 9 percent in 1940 and has remained constant since then. ${ }^{29}$

\footnotetext{
${ }^{28}$ The percent of independent households headed by nonmarried women with no children present has risen from 46 percent in 1910 to 60 percent in 1940 and to 87 percent in 1990. Change in this variable is related both to children leaving home earlier and to an earlier stopping of fertility. Estimated from the integrated public use census samples (Ruggles and Sobek 1995).

${ }^{29}$ In 191042 percent of these women were farmers, 18 percent worked in private households, 12 percent as operatives, and 11 percent were in the service sector. In 1940 the fraction of farmers had fallen to 18 percent, the fraction working in private households remained constant at 18 percent, and the other most common occupations were managerial and operative (14 percent each). In 199030 percent were employed in the clerical sector, 23 percent
} 


\section{Appendix B}

\section{Sources of Data}

- Fraction of older nonmarried women living with family. 1940 and 1950 public use census samples.

- Average OAA payment.

Friedberg (1996), adjusted for state cost of living using Appendix I, Williamson and Lindert (1980). The cost of living index for 1940 was interpolated from 1930 and 1950 values.

- OAA recipiency rate.

Friedberg (1996).

- Dummies for relatives responsibility laws, lien laws, citizenship laws, and whether financed by county funds.

Various issues of U.S. Federal Security Agency, Characteristics of State Plans ... and Epler (1954)

- Fraction older nonmarried women white, foreign-born, never finished elementary school. 1940 and 1950 public use census samples.

- Fraction labor force agricultural.

Table L-5 in Lee et al. (1957: 623-31).

- Daughter-mother ratio and income of household heads age 25 to 44.

1940 and 1950 public use census samples.

- Average AFDC Payment.

Various issues of Social Security Bulletin.

\section{References}

[1] 1994-1995 Advisory Council on Social Security. Technical Panel on Trends and Issues in Retirement Saving. Final Report. September 29, 1995. http://www.ssa.gov/policy/tirs1.txt.

[2] Bond, Floyd A., Ray E. Baber, John A. Vieg, Louis B. Perry, Alvin H. Scaff, and Luther J. Lee, Jr. 1954. Our Needy Aged: A California Study of a National Problem. New York: Henry Holt and Company.

in the service sector, 15 percent were professionals, and 10 percent were in sales. Estimated from the integrated public use census samples (Ruggles and Sobek 1995). 
[3] Börsch-Supan, Axel. 1989. "Household Dissolution and Alternative Living Arrangements." In David A. Wise (Ed.), The Economics oF Aging. Chicago: The University of Chicago Press. 119-149.

[4] Börsch-Supan, Axel, V. Hajivassiliou, J. Kotlikoff, and J.N. Morris. 1992. "Health, Children, and Elderly Living Arrangements." In David A. Wise (Ed.), Topics in the Economics of Aging. Chicago: The University of Chicago Press: 79-104.

[5] Breckenridge, Donna Baker-Greenway. 1989. "Trends in Age Heterogamy Among NativeBorn Americans, 1800-1950.” Unpublished Phd. Dissertation. Brigham Young University.

[6] Brown, J. Douglas. 1977. Essays on Social Security. Princeton, NJ: Industrial Relations Sections, Princeton University.

[7] Burkhauser, Richard V. and Timothy R. Smeeding. 1994. "Social Security Reform: A Budget Neutral Approach to Reducing Older Women's Disportionate Risk of Poverty." Maxwell School, Center for Policy Research, Policy Brief No. 2.

[8] Epler, Elizabeth. 1954. "Old-Age Assistance: Plan Provisions on Children's Responsibility for Parents." Social Security Bulletin. April: 3-12.

[9] Epstein, Lenore A. 1955. "Economic Resources of Persons Aged 65 and Over." Social Security Bulletin. June: 3-33.

[10] Friedberg, Leora F. 1996. The Effect of Government Programs on the Labor Supply of the Elderly. Unpublished PhD Dissertation. Massachusetts Institute of Technology.

[11] Graebner, William. 1980. A History of Retirement: The Meaning and Function of an American Institution. New Haven: Yale University Press.

[12] Haines, Michael R. 1996. "Long-term Marriage Patterns in the United States from Colonial Times to the Present." The History of the Family. 1(1): 15-39.

[13] Hanmer, Frank J. 1957. "Recipients of Old Age Assistance: Personal and Social Characteristics.” Social Security Bulletin. April: 3-13.

[14] Hsiao, Cheng. 1986. Analysis of Panel Data. Cambridge: Cambridge University Press.

[15] Kobrin, Francis E. 1976. "The Fall in Household Sizc and the Rise of the Primary Individual in the United States." Demography. 13: 127-138.

[16] Lee, Everett S., Ann Ratner Miller, Carol P. Brainerd, and Richard Easterlin. 1957. Population Redistribution and Economic Growth: United States, 1870-1950. Vol. 1: Methodological Considerations and Reference Tables. Philadelphia: The American Philosophical Society. 
[17] Longino, Charles F. Jr. 1990. "Geographical Distribution and Migration.” In R.H. Binstock and Linda K. George (Eds.), Handbook of Aging and the Social Sciences. San Diego, CA: Academic Press: 45-63.

[18] McGarry, Kathleen and Robert F. Schoeni. 1995. "Transfer Behavior in the Health and Retirement Study: Measurement and the Redistribution of Resources within the Family." Journal of Human Resources. 30(Supplement): S184-S226.

[19] Michael, Robert T., Victor R. Fuchs, and Sharon R. Scott. 1980. "Changes in the Propensity to Live Alone, 1950-1976." Demography. 17: 39-56.

[20] National Civic Federation. Industrial Welfare Department. 1928. Extent of Old Age Dependency. New York: National Civic Federation.

[21] Preston, Samuel H., Nathan Keyfitz,and Robert Schoen. 1972. Causes of Death: Life Tables for National Populations. New York: Seminar Press.

[22] Ruggles, Steven and Matthew Sobek. 1995. Integrated Public Use Microdata Series, IPUMS95 Version 1.0. Social History Research Laboratory. Minneapolis, MN: Department of History. University of Minnesota. http://www.hist.umn.edu/ ipums/.

[23] Schorr, Alvin L. 1960. Filial Responsibility in the Modern American Family: An Evaluation of Current Practice of Filial Responsibility in the United States and the Relationship to it of Social Security Programs. Washington, DC: U. S. Dept. of Health, Education, and Welfare, Social Security Administration, Division of Program Research.

[24] Schwartz, Saul, Sheldon Danziger, and Eugene Smolensky. 1984. "The Choice of Living Arrangements by the Elderly." In Henry J. Aaron and Gary Burtless (Eds.), Retirement and Economic Behavior, Washington DC: The Brookings Institution: 229-253.

[25] Shearon, Marjorie. 1938. "Economic Status of the Aged." Social Security Bulletin. March: 5-16.

[26] Steiner, Peter O. and Robert Dorfman. 1957. The Economic Status of the Aged. Berkeley and Los Angeles: The University of California Press.

[27] Quadagno, Jill S. 1988. The Transformation of Old Age Security: Class and Politics in the American Welfare State. Chicago, IL: University of Chicago Press.

[28] U.S. Bureau of the Census. 1975. Historical Statistics of the United States, Colonial Times to 1970 . Washington: GPO.

[29] U.S. Bureau of the Census. 1993. Statistical Abstract of the United States: 1993. Washington, DC: Government Printing Office. 
[30] U.S. Federal Security Agency. 1950. Characteristics of State Public Assistance Plans; Old Age Assistance, Aid to the Blind, Aid to Dependent Children. Washington DC: Social Security Administration, Bureau of Public Assistance, Public Assistance Report No. 18.

[31] U.S. Federal Security Agency. 1948. Supplement to Characteristics of State Plans; Old-Age Assistance, Aid to the Blind, Aid to Dependent Children. Washington DC: Social Security Administration, Bureau of Public Assistance.

[32] U.S. Federal Security Agency. 1946. Characteristics of State Plans: Old-Age Assistance, Aid to the Blind, Aid to Dependent Children. Washington DC: Social Security Administration, Bureau of Public Assistance.

[33] U.S. Federal Security Agency. 1940. Characteristics of State Plans for Old Age Assistance. Social Security Board Publication No. 16. Prepared by the Bureau of Public Assistance. Washington DC: Government Printing Office.

[34] U.S. Social Security Board. 1939. Characteristics of State Plans for Old Age Assistance. Washington: Government Printing Office.

[35] U.S. Social Security Board. 1945. Preliminary Tables on Incomes and Living Arrangements of Recipients of Old Age Assistance in 21 States. 1944. Washington DC: Federal Security Agency, Bureau of Public Assistance.

[36] White, Ruth and Thomas G. Hutton. 1948. "Requirements and Incomes of Recipients of Old-Age Assistance in 21 States in 1944." Statistics and Analysis Division. Bureau of Public Assistance. Public Assistance Report No. 13. Federal Security Agency.

[37] Williamson, Jeffrey G. and Peter H. Lindert. 1980. American Inequality: A Macroeconomic History. New York: Academic Press.

[38] Wolf, Douglas A. 1995. "Changes in the Living Arrangements of Older Women: An International Study." The Gerontologist. 35(6): 724-731.

[39] Wolf, Douglas A. 1994. "The Elderly and Their Kin: Patterns of Availability and Access." In L.G. Martin and S.A. Preston (Eds.), Demography of Aging. Washington, DC: National Academy Press: 146-194. 